\title{
KEWARISAN ANAK ANGKAT YANG BERKEDUDUKAN SEBAGAI ASHÂBUL FURÛDH \\ (Analisis Terhadap Putusan Pengadilan Agama No. 287/Pdt.G/2006/PA.Pdg.)
}

\author{
Dodon Alfiander \\ Fakultas Syari'ah IAIN Batusangkar \\ J1. Jenderal Sudirman No. 137, Lima Kaum Batusangkar \\ e-mail: dodonalfiander@iainbatusangkar.ac.id
}

\begin{abstract}
Abstrak: The Case No. 287/Pdt. G/2006/PA.Pdg. is a lawsuit Wasiat Wajibah submitted to the Religious Court of Padang. The Religious Court of Padang sets the plaintiff on this case as an adopted child who is entitled to obtain a mandatory will from his foster mother's estate. Where as between the plaintiff and his adoptive mother has a very close kinship relationship. The plaintiff is the real child of his adoptive brother's brother, while at that moment the plaintiff's adoptive mother was the heir of Kalalah. The Law of Inheritance of Islam recognized the right of inheritance to the sister's child. Sister's son's inheritance is not clearly contained in the Qur'an and the hadith of the Prophet Muhammad pbuh. However, sister's child's inheritance rights are basically through the extension of the understanding of other whose rights are described in the Qur'an, because if he or she has no sister and brother, the position can be replaced by the child. Sister's child will not get the right as long as his father who connects him to the heir is alive. This can be understood as the concept of "Expanding Brotherhood Meanings". Thus, the decision of the Religious Court of Padang on the Wasiat Wajibah which sets the plaintiff to obtain the right to the property of his adoptive mother through Wasiat Wajibah is not appropriate. This is because the plaintiff has a very close kinship with his adoptive mother. Therefore, the plaintiff is more aptly part of the heritage of his adoptive mother through his right as an heir (ashâbul furûdh), not as a mandatory will. This is because the plaintiff replaces the position of his biological father as the heir because he has died earlier than his adoptive mother. The Plaintiff is entitled to receive a share of furuldh against the inheritance of his adopted mother. The furûdh portion obtained is based on the letter of al-Nisâ verse 176.
\end{abstract}

Kata kunci: kewarisan, anak angkat, wasiat wajibah, kalâlah, ashâbul furûdh.

\section{PENDAHULUAN}

$\mathscr{T}$ erkara Wasiat Wajibah dengan nomor perkara 287/Pdt.G/2006/PA.Pdg. ini diajukan ke Pengadilan Agama Padang oleh Rosmeily binti Abdul Azis. Perkara ini diajukan untuk pengambilan atau pencairan harta atau dokumen penting almarhumah $\mathrm{Hj}$. Syamsiar (orang tua angkat penggugat) yang ada pada Bank Pembangunan Daerah (BPD) dan Bank Rakyat Indonesia (BRI) Sumatera Barat. Namun dalam pencairan deposito orang tua angkatnya, penggugat mengalami permasalahan, yaitu pihak bank tidak bisa mencairkan deposito tersebut tanpa ada penetapan ahli waris dari Pengadilan. 
Dalam perkara ini Majelis Hakim pada Pengadilan Agama Padang mengabulkan gugatan Penggugat dengan menetapkan penggugat Rosmeily binti Abdul Aziz sebagai Anak Angkat yang berhak mendapatkan bagian dari harta peninggalan Ibu Angkatnya (Almarhumah Hj. Syamsiar) melalui Wasiat Wajibah.

Memperhatikan putusan Majelis Hakim pada Perkara Wasiat Wajibah tersebut, penulis berpendapat bahwa penetapan Majelis Hakim atas Penggugat yang berhak mendapatkan bagian dari harta peninggalan Ibu Angkatnya (Almarhumah Hj. Syamsiar) melalui wasiat wajibah adalah kurang tepat. Hal ini dikarenakan apabila dilihat dari hubungan kekerabatan di antara Penggugat (Rosmeily binti Abdul Aziz) dengan ibu angkatnya (Hj. Syamsiar), maka di antara mereka terlihat hubungan kekerabatan yang sangat erat, karena ayah penggugat (Abdul Azis) adalah saudara kandung dari ibu angkat penggugat (Berkas Perkara No. 287/ Pdt. G/ 2006/ PA. Pdg.).

Melihat kepada hubungan kekerabatan yang demikian erat itu, disebabkan karena ayah penggugat merupakan saudara kandung dari almarhum ibu angkatnya (Almarhumah Hj. Syamsiar), maka apabila ditinjau dari konsep kewarisan Islam, posisi mereka yang saling bersaudara tersebut dapat saling mewarisi.

Kedudukan saudara, baik saudara kandung, saudara seayah, ataupun saudara seibu, baik laki-laki maupun perempuan adalah merupakan ahli waris. Hak kewarisan saudara dijelaskan secara langsung dalam al-Qur'an, yaitu surat alNisâ ayat 12 dan 176. Berdasarkan dalil ini saudara dapat saling mewarisi terhadap harta yang ditinggalkan. Namun apabila melihat kepada perkara penetapan wasiat wajibah sebagaimana yang telah dijelaskan di atas, timbul persoalan bahwa keberadaan Abdul Aziz (yang merupakan ayah kandung dari penggugat) telah terlebih dahulu meninggal dunia dari pada pewaris (Hj. Syamsiar) yang juga merupakan ibu angkat dari penggugat. Sementara itu $\mathrm{Hj}$. Syamsiar yang merupakan Ibu Angkat dari penggugat tidak memiliki ahli waris lagi yang ditinggalkan. Ia hanya meninggalkan penggugat beserta 4 (empat) orang saudara penggugat lainnya (Desparika Metra, "Syariah Konsultan", Jln. Kp. Lalang By Pass Lampu Merah Padang). Dalam kondisi seperti ini, dapat dipahami bahwa Hj. Syamsiar sebagai pewaris dapat digolongkan kepada pewaris kalâlah. Kata kalâlah dipergunakan secara hakikat untuk seseorang yang tidak punya ayah dan anak (Ibn Manzur, t.th: 142).

Hj. Syamsiar sebagai ahli waris pada saat ia meninggal dunia hanya meninggalkan lima orang ahli waris yang keseluruhannya adalah merupakan anak kandung dari saudara laki-laki kandungnya yang telah terlebih dahulu meninggal dunia darinya. Di antara lima ahli waris tersebut salah satunya adalah merupakan anak angkatnya yaitu Rosmeily binti Abdul Aziz.

Sehubungan dengan kewarisan terhadap anak dari saudara kandung ini, diketahui bahwa tidak ada ketentuan yang mengatur secara eksplisit (baik berupa ketentuan al-Qur'an, sunnah, ataupun ketentuan berupa peraturan perundang-undangan positif khususnya di Indonesia) terhadap persoalan ini. Dengan demikian, hal ini memunculkan 
persoalan bahwa dengan meninggalnya Abdul Aziz terlebih dahulu dari pada pewaris (Hj. Syamsiar), apakah kedudukannya sebagai ahli waris dapat digantikan oleh anak kandungnya sendiri?.

Di sisi lain diketahui bahwa Abdul Aziz yang dalam hal ini merupakan ahli waris yang pada saat itu telah terlebih dahulu meninggal dunia dari pada pewaris, meninggalkan lima orang anak yang terdiri dari empat orang anak perempuan serta satu orang anak lakilaki. Bagaimana pula ketentuan pembagian beserta furûdh yang dapat diterima oleh anak-anaknya terhadap harta peninggalan ahli waris tersebut?

\section{METODE PENELITIAN}

\section{Jenis Penelitian}

Jenis penelitian ini adalah penelitian hukum normatif. Penelitian ini merupakan penelitian kepustakaan (library research) dengan pendekatan studi dokumentasi. Dalam hal ini, dokumentasi yang digunakan adalah putusan Pengadilan Agama Nomor 287/Pdt.G/2006/PA.Pdg.

2. Metode Pengumpulan Data dan Sumber Data

Teknik pengumpulan data merupakan langkah awal bagi seorang peneliti untuk menemukan sesuatu yang berhubungan dengan objek penelitiannya. Teknik pengumpulan data sangat berhubungan erat dengan penentuan sumber data.

Berdasarkan klasifikasi data yang ada, data terbagi dua, yaitu data primer dan data sekunder. Data primer adalah data yang diperoleh seorang peneliti langsung dari sumber pertama, sedangkan data sekunder adalah data yang diperoleh seorang peneliti secara tidak langsung dari sumbernya, tapi melalui sumber lain. Namun, sumber data yang digunakan dalam penelitian ini adalah sumber sekunder.

Sumber sekunder yang digunakan dalam penelitian ini pun terbagi menjadi tiga bentuk, yaitu bahan primer, sekunder dan tersier (J. Suprapto, 2003: 3). Adapun yang dijadikan sebagai bahan primer dalam penelitian ini yaitu putusan Pengadilan Agama Nomor 287/ Pdt.G/ 2006/ PA. Pdg. Sedangkan yang menjadi bahan sekundernya yaitu peraturan perundangundangan yang mengatur tentang Wasiat Wajibah, yaitu Kompilasi Hukum Islam Tahun 1991. Sedangkan yang menjadi bahan tersiernya yaitu berupa kamus, ensiklopedia dan lain-lain.

3. Pengolahan Data

Merupakan upaya penulis dalam mengolah data-data yang telah didapatkan, dengan cara menghimpun data-data yang penulis butuhkan, membaca, menganalisa, merumuskan buku-buku, jurnal ilmiah, literatur-literatur lainnya yang penulis gunakan, menyeleksi bahan-bahan agar dapat dipisahkan antara data yang relevan dengan data yang tidak relevan dengan kajian ini.

4. Analisis Data

Data yang berkaitan dengan peraturan perundang-undangan yang mengatur tentang wasiat wajibah dianalisa dengan menggunakan metode berfikir induktif. Sedangkan data yang dikumpulkan dalam bentuk putusan pengadilan diolah dengan menggunakan teknik analisis kualitatif 
dengan pendekatan contents analysis (analisis isi).

\section{PEMBAHASAN}

Analisis Terhadap Putusan Pengadilan Agama Padang Tentang Penetapan Wasiat Wajibah

\section{Penetapan Wasiat Wajibah}

Pelaksanaan atau peristiwa pengangkatan anak mengakibatkan ketentuan hukum baru. Pada saat salah satu atau bahkan kedua orang tua angkat tersebut meninggal dunia, maka akan terjadi perubahan sosial tentang pembagian harta warisan yang ditinggalkan. Kedudukan anak angkat/orang tua angkat pada hukum waris yang diatur dalam ketentuan hukum adat, keduanya adalah ahli waris yang saling mewarisi. Sementara menurut Kompilasi Hukum Islam anak angkat/orang tua angkat berhak mendapatkan wasiat wajibah sebanyak $1 / 3$ apabila anak angkat/orang tua angkat tidak menerima wasiat. Di samping itu menurut Kitab Undang Undang Hukum Perdata pada pasal 832 serta dalam ketentuan hukum Islam, keduanya bukanlah termasuk ahli waris.

Memperhatikan ketentuan Kompilasi Hukum Islam tentang pembagian harta peninggalan orang tua angkat terhadap anak angkat ini, ketentuan terhadap persoalan ini diakomodir pada bab yang mengatur mengenai persoalan wasiat, yaitu dalam pasal 194-209. Selain mengatur persoalan wasiat biasa, KHI juga mengatur dan mengintrodusir hal baru dalam khasanah hukum Islam di
Indonesia, yaitu persoalan wasiat wajibah. Sayangnya, KHI tidak memberikan defenisi dalam Ketentuan Umum tentang wasiat wajibah tersebut. KHI mempunyai ketentuan tersendiri tentang wasiat wajibah dan berbeda dalam pengaturannya dari negaranegara Muslim lainnya. Konsep KHI adalah memberikan wasiat wajibah terbatas pada anak angkat dan orang tua angkat, sementara negara lainnya seperti Mesir, Maroko, Suriah, dan Tunisia melembagakan wasiat wajibah untuk mengatasi persolaan cucu yang orang tuanya meninggal terlebih dahulu daripada kakek atau neneknya (Cik Hasan Bisri, 1999: 88-89), sementara di Indonesia ketentuan terhadap persoalan ini diatur dalam ketentuan ahli waris pengganti yang dimuat pada pasal $185 \mathrm{KHI}$.

Salah satu persoalan/sengketa yang berhubungan dengan wasiat yang menjadi kewenangan absolut hakim Pengadilan Agama yang telah diperiksa dan diputus oleh Pengadilan Agama adalah perkara Wasiat Wajibah Nomor 287/Pdt.G/2006/PA.Pdg., yang telah diputus oleh Pengadilan Agama Padang pada tahun 2006.

Adapun yang melatarbelakangi gugatan wasiat wajibah ini adalah untuk mencairkan deposito orang tua angkatnya yang ada pada bank BNI cabang Padang. Namun, pihak bank tidak mau mencairkan deposito tersebut sebelum ada surat penetapan ahli waris dari Pengadilan. Pengadilan Agama tidak bisa mengeluarkan surat penetapan ahli waris, karena anak angkat bukanlah ahli waris. Oleh sebab itulah, Rosmeily mengajukan surat 
gugatan wasiat wajibah ke Pengadilan Agama Padang.

Dalam perkara ini Majelis Hakim pada Pengadilan Agama Padang mengabulkan gugatan penggugat dengan menyatakan penggugat Rosmeily binti Abdul Aziz adalah merupakan anak angkat dari Safaruddin dan Hj. Syamsiar, serta berhak mendapatkan bagian dari harta peninggalan Ibu Angkatnya $\mathrm{Hj}$. Syamsiar melalui Wasiat Wajibah. Kenyataan yang demikian itu memunculkan pertanyaan bahwa dengan adanya peristiwa pengangkatan anak tersebut, apakah dengan serta merta mengakibatkan anak angkat/orang tua angkat mendapatkan wasiat wajibah?

Ketentuan mengenai wasiat wajibah diatur di dalam pasal 209 ayat (1) dan (2) Kompilasi Hukum Islam, yaitu:

(1) Harta peninggalan anak angkat dibagi berdasarkan pasal-pasal 176 sampai dengan pasal 193 tersebut di atas, sedangkan terhadap orang tua angkat yang tidak menerima wasiat diberi wasiat wajibah sebanyak-banyaknya 1/3 dari harta warisan anak angkatnya.

(2) Terhadap anak angkat yang tidak menerima wasiat diberi wasiat wajibah sebanyak-banyaknya $1 / 3$ dari harta warisan orangtua angkatnya.

Berdasarkan peraturan tersebut di atas, pelaksanaan wasiat wajibah tidaklah bersifat memaksa atau bukan bersifat imperatif, melainkan pelaksanaannya dilakukan secara tentatif. Sehingga pasal tersebut dapat dipahami bahwa wasiat wajibah dapat atau tidak dapat diberikan kepada orang tua angkat/anak angkat. Pada akhirnya defenisi wasiat wajibah dapat dipahami sebagai kewajiban seseorang dalam keadaan tertentu untuk berwasiat terhadap anak angkat atau orangtua angkat yang bila wasiat tersebut tidak dilaksanakan maka Pengadilan Agama dapat menetapkan ia telah berwasiat.

Ada beberapa hal yang menyebabkan seorang anak angkat atau orang tua angkat tidak dapat memperoleh wasiat wajibah, yaitu:

Pertama, anak angkat/orang tua angkat sebelumnya telah menerima wasiat dari pewaris. Kedua, secara hukum terhalangnya untuk mendapatkan bagian harta warisan. Ketiga, peristiwa hukum meninggalnya pewaris terjadi sebelum berlakunya Kompilasi Hukum Islam, sedangkan gugatan/tuntutan diajukan ke Pengadilan Agama setelah berlakunya kompilasi Hukum Islam yang memberikan peluang kepada anak angkat/orang tua angkat untuk mendapatkan wasiat wajibah. Berdasarkan hal ini, dapat dicermati bahwa tidak ada hal-hal yang dapat menghalangi Rosmeily binti Abdul Azis untuk mendapatkan wasiat wajibah dari orang tua angkatnya, dengan demikian putusan terhadap gugatan Rosmeily binti Abdul Azis oleh majelis hakim dipandang sudah tepat/benar.

Namun apabila mencermati hubungan kekerabatan antara Penggugat Rosmeily binti Abdul Aziz dengan Hj. Syamsiar (Alm.) sebagai ibu angkatnya, maka di antara mereka akan terlihat hubungan kekerabatan yang sangat erat. Ayah kandung penggugat yaitu Abdul Azis, merupakan saudara kandung dari ibu 
angkat penggugat. Melihat kepada hubungan kekerabatan yang demikian erat itu, disebabkan karena ayah penggugat merupakan saudara kandung dari almarhum ibu angkatnya, maka apabila ditinjau dari konsep kewarisan Islam, posisi mereka yang saling bersaudara tersebut dapat saling mewarisi.

Hak kewarisan saudara dijelaskan secara langsung dalam al-Qur'an, yaitu surat al-Nisâ ayat 12 dan 176. Para ahli tafsir menjelaskan bahwa kewarisan saudara seibu, baik laki-laki maupun perempuan diatur dalam ayat 12, sementara saudara kandung maupun saudara seayah, baik laki-laki maupun perempuan diatur dalam surat Al-Nisa ayat 176 (Amir Syarifuddin, 2004: 215).

Lebih lanjut, sesuai dengan fakta yang terungkap pada persidangan perkara wasiat wajibah ini, bahwa ibu angkat penggugat yaitu $\mathrm{Hj}$. Syamsiar pada saat ia meninggal dunia tidak meninggalkan seorang ahli warispun kecuali anak angkatnya yaitu Rosmeily binti Abdul Azis beserta empat orang saudara Rosmeily lainnya (yang terdiri dari tiga orang perempuan dan satu orang laki-laki) (Berkas Perkara No. 287/ Pdt. G/ 2006/ PA. Pdg.). Rosmeily beserta empat orang saudaranya yang lainnya merupakan anak kandung dari Abdul Azis. Abdul azis pun pada saat itu telah meninggal dunia terlebih dahulu daripada Hj. Syamsiar. Artinya pada saat itu $\mathrm{Hj}$. Syamsiar hanya meninggalkan lima orang anak kandung dari saudara laki-laki kandungnya sendiri, termasuk Rosmeily yang juga merupakan anak angkatnya.
Dalam kasus sebagaimana yang digambarkan di atas, melihat kepada hubungan kekerabatan ayah penggugat (Abdul Azis) adalah saudara kandung dari ibu angkat penggugat $(\mathrm{Hj}$. Syamsiar), serta memperhatikan kondisi ahli waris yang ditinggalkan oleh Hj. Syamsiar pada waktu itu, maka hubungan kewarisan mereka dapat diperhatikan pada surat al-Nisâ ayat 176 sebagai berikut :

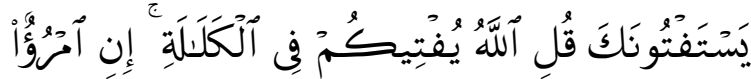

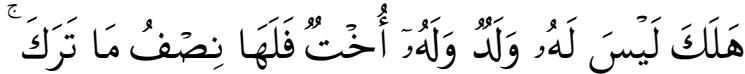

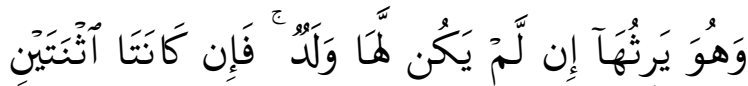

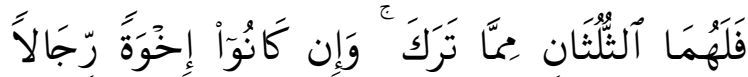

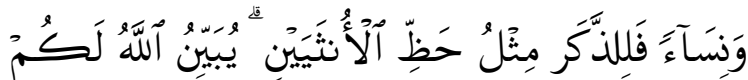

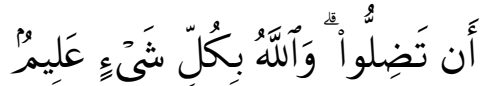

"Mereka meminta fatwa kepadamu (tentang kalâlah). Katakanlah: "Allah memberi fatwa kepadamu tentang kalâlah (yaitu): jika seorang meninggal dunia, dan ia tidak mempunyai anak dan mempunyai saudara perempuan, Maka bagi saudaranya yang perempuan itu seperdua dari harta yang ditinggalkannya, dan saudaranya yang laki-laki mempusakai (seluruh harta saudara perempuan), jika ia tidak mempunyai anak; tetapi jika saudara perempuan itu dua orang, Maka bagi keduanya dua pertiga dari harta yang ditinggalkan oleh yang meninggal. dan jika mereka (ahli waris itu terdiri dari) Saudara-saudara laki dan perempuan, Maka bahagian seorang saudara laki-laki 
sebanyak bahagian dua orang saudara perempuan. Allah menerangkan (hukum ini) kepadamu, supaya kamu tidak sesat. dan Allah Maha mengetahui segala sesuatu". (Q.S. Al-Nisâ [4] : 176).

Memperhatikan surat al-Nisâ ayat 176 di atas, maka dapat diambil beberapa poin kesimpulan, bahwa ayat 176 berbicara mengenai dua hal :

1. Kalâlah didefenisikan sebagai "seseorang yang meninggal dunia dan tidak ada meninggalkan anak".

2. Bila pewaris adalah kalâlah, saudara menerima hak dengan uraian sebagai berikut :

a. Seorang saudara perempuan saja mendapat $1 / 2$

b. Dua orang (atau lebih) saudara perempuan mendapat $2 / 3$

c. Bila bergabung saudara laki-laki dan perempuan, mereka menerima dengan bandingan seorang saudara laki-laki sebesar bagian dua orang perempuan.

Memperhatikan kondisi sebagaimana yang digambarkan di atas, bahwa hak kewarisan saudara kandung diatur secara jelas pada surat al-Nisâ ayat 176, sementara faktanya Hj. Syamsiar tidak meninggalkan saudara kandung sebagai ahli waris, melainkan hanya meninggalkan anak dari saudara kandungnya. Dengan demikian, hak terhadap anak saudara diperoleh berdasarkan perluasan pengertian dari saudara yang haknya telah dijelaskan dalam al-Qur'an. Jika saudara sudah tidak ada, maka kedudukannya digantikan oleh anaknya, dan anak saudara itu belum akan mendapatkan hak selama ayahnya yang menghubungkannya kepada pewaris masih hidup (Amir Syarifuddin, 2004: 218).

Dalam usaha memperluas pengertian saudara kepada anak saudara, ulama Ahlu Sunnah sepertinya berpedoman kepada hadis Nabi (Al-Nawawi, 1972: 52), yaitu :

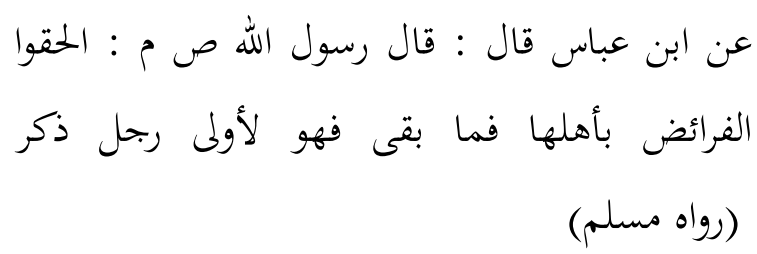

"Dari Ibnu Abbas ia berkata: Rasul SAW telah bersabda: berikan bagian faraid kepada yang berhak sisanya adalah untuk kerabat laki-laki yang terdekat". (Hadis Riwayat Muslim).

Sementara itu golongan Syi'ah tidak berpedoman kepada hadis yang digunakan oleh ulama Ahlu Sunnah di atas. Golongan Syi'ah tetap tidak membedakan antara laki-laki dan perempuan. Mereka menempatkan laki-laki atau perempuan, yang ia adalah anak dari saudara laki-laki atau perempuan, kandung, seayah, atau seibu, adalah ahli waris dengan nama anak saudara (Abu Ja'far Muhammad Husain bin 'Ali al-Thusy, t.th; 9).

Berdasarkan uraian di atas dapat dipahami bahwa baik ulama Ahlu Sunnah maupun ulama Syi'ah, telah sepakat bahwa hak kewarisan dari saudara dapat digantikan oleh anak kandung dari saudara tersebut. Dan itu berarti bahwa dalam perkara ini, Rosmeily beserta empat orang saudaranya yang lainnya merupakan ahli waris dari $\mathrm{Hj}$. Syamsiar, mereka 
menggantikan posisi ayah kandung mereka yaitu Abdul Azis yang telah terlebih dahulu meninggal dunia dari pada pewaris.

Dengan demikian penulis berpendapat bahwa putusan majelis hakim yang menetapkan penggugat Rosmeily binti Abdul Azis mendapatkan hak atas harta peninggalan ibu angkatnya $\mathrm{Hj}$. Syamsiar melalui wasiat wajibah kurang tepat. Penulis melihat bahwa Rosmeily binti Abdul Azis lebih tepat mendapatkan bagian atas harta peninggalan $\mathrm{Hj}$. Syamsiar tersebut melalui haknya sebagai ahli waris (Dodon Alfiander, 2015: 125). Hal ini disebabkan karena :

a. Memperhatikan hubungan kekerabatan antara Rosmeily (penggugat) dengan ibu angkatnya Hj. Syamsiar, terlihat hubungan kekerabatan di antara mereka sangatlah erat. Rosmeily merupakan anak angkat yang juga sekaligus adalah anak kandung dari saudara laki-laki kandung

Hj. Syamsiar (pewaris). Hal ini menyebabkan antara Hj. Syamsiar dengan Rosmeily memiliki hubungan kewarisan. Dengan kata lain Rosmeily adalah ahli waris dari Hj. Syamsiar. Hal ini disebabkan karena Rosmeily menggantikan posisi almarhum ayah kandungnya Abdul Azis yang telah terlebih dahulu meninggal dunia dari Hj. Syamsiar.

b. Hadis Nabi SAW yang diriwayatkan dari Abi Umâmah al-Bâhilî (Abi 'Isa Muhammad 'Isa ibn Sautah al-Turmudzi, 2000: 178), yaitu:

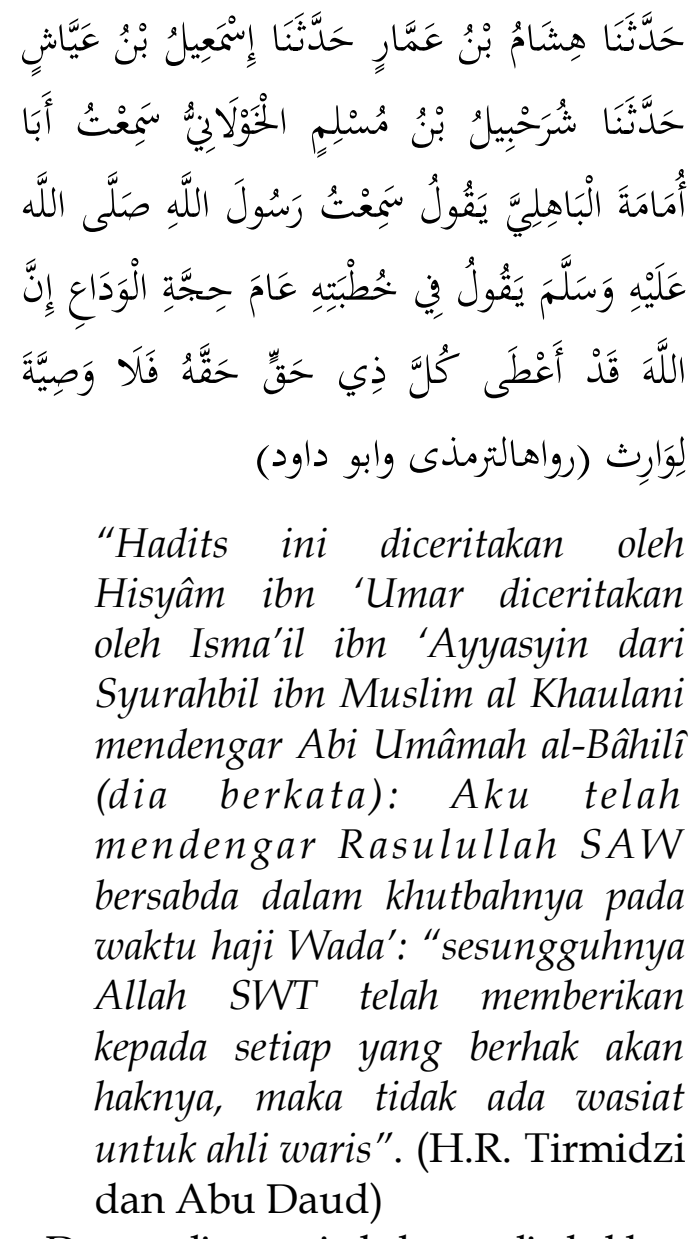

Dapat dicermati bahwa disebabkan karena Rosmeily merupakan ahli waris yang berhak mendapatkan hak kewarisan dari harta peninggalan $\mathrm{Hj}$. Syamsiar, dengan demikian Rosmeily tidak berhak mendapatkan bagian terhadap harta peninggalan $\mathrm{Hj}$. Syamsiar melalui wasiat wajibah.

2. Penyelesaian Problematika Penetapan Wasiat Wajibah Serta Kaitannya dengan Posisi Penggugat Sebagai Penerima Wasiat Wajibah dan Ashâbul Furûdh.

Memperhatikan posisi kelima anak kandung Abdul Azis yang merupakan ahli waris dari $\mathrm{Hj}$. Syamsiar, salah satu di antaranya adalah anak angkat dari $\mathrm{Hj}$. Syamsiar 
tersebut, yang juga merupakan penggugat dalam perkara ini, yaitu Rosmeily. Kondisi ini memunculkan pertanyaan tentang bagaimana kedudukan/ posisi Rosmeily terhadap empat orang saudaranya yang lainnya yang juga merupakan ahli waris. Tidak hanya itu, hal ini juga berkaitan serta berimplikasi terhadap bagaimana ketentuan pembagian furûdh di antara mereka. Berapakah furûdh yang berhak di terima oleh masing-masing mereka sebagai ahli waris?.

Pada prinsipnya anak saudara kandung mendapat warisan bila sudah tidak ada saudara seayah dan orang yang menghijab saudara seayah itu. Sedangkan anak saudara seayah mendapat warisan bila sudah tidak ada anak saudara kandung dan tidak ada pula orang-orang yang menutupnya. Anak saudara seibu (hanya dalam pandangan syi'ah) mendapat warisan bila tidak ada saudara seibu dan orang yang menutupi saudara seibu itu (Amir Syarifuddin, 2004: 219).

Memperhatikan fakta mengenai kondisi ahli waris yang ditinggalkan oleh Hj. Syamsiar, bahwa ia tidak meninggalkan ahli waris lain selain anak saudara kandungnya Abdul Azis. Di sisi lain Abdul Azis pun telah terlebih dahulu meninggal dunia daripada Hj. Syamsiar. Dengan demikian, dapat dipahami bahwa dalam kondisi yang demikian itu lima orang anak Abdul Azis tersebut adalah merupakan ahli waris dzaul furûdh yang berhak mewarisi seluruh harta peninggalan $\mathrm{Hj}$. Syamsiar. Hal ini disebabkan karena mereka berposisi mengantikan kedudukan ayah mereka (Abdul Azis), serta tidak ada pula ahli waris lain bersama mereka yang dapat menghijab/menghalangi posisi mereka dalam mewarisi harta $\mathrm{Hj}$. Syamsiar. Oleh karena itu mereka berhak mendapat bagian furûdh dari harta peninggalan $\mathrm{Hj}$. Syamsiar.

Dapat dicermati bahwa kedudukan Abdul Aziz sebagai ahli waris yang posisinya digantikan oleh anak-anaknya dalam menerima hak kewarisan jika seandainya ia masih hidup pada saat itu adalah bukan berposisi sebagai ahli waris dzaul furûdh, akan tetapi ia adalah sebagai ashâbah bi al-nafsihi yang berhak mewarisi seluruh harta $\mathrm{Hj}$. Syamsiar. Posisinya sebagai ashâbah itu disebabkan karena pada saat $\mathrm{Hj}$. Syamsiar meninggal dunia, ia tidak meninggalkan ahli waris lain selain Abdul Azis beserta lima orang anak Abdul Azis. Dengan demikian, pada saat itu hanya Abdul Azis lah yang berhak menjadi ahli waris, dan posisinya menghijab kelima orang anaknya pada saat itu.

Akan tetapi karena Abdul Azis telah terlebih dahulu meninggal dunia daripada $\mathrm{Hj}$. Syamsiar, maka kedudukannya itu digantikan oleh kelima orang anak kandungnya. Dalam menggantikan kedudukan Abdul Azis sebagai ahli waris, kelima orang anaknya tersebut tidak berposisi sebagai ashâbah bi al-nafsihi sebagaimana Abdul Azis, melainkan kelima anaknya tersebut berposisi sebagai dzaul furûdh. 
Adapun alasan mengapa kelima anak Abdul Azis tersebut dikategorikan kepada ahli waris dzaul furûdh pada saat itu adalah disebabkan karena: Pertama, keberadaan mereka sebagai ahli waris yang dapat menggantikan kedudukan ayah mereka Abdul Azis pada saat itu adalah berdasarkan konsep "perluasan pengertian saudara kepada anak saudara" manakala saudara telah terlebih dahulu meninggal dunia daripada pewaris, serta tidak adanya orang-orang yang dapat menghijab keberadaan saudara jika seandainya pada saat itu saudara tersebut masih hidup. Kedua, pada saat itu pewaris (Hj. Syamsiar) meninggal dunia dalam kondisi kalâlah. Kata kalâlah adalah bentuk masdar dari kata "kalla" yang secara bahasa berarti letih atau lemah. Kata kalâlah ini pada asalnya digunakan untuk menunjukkan pada sesuatu yang melingkarinya, yang tidak berujung ke atas dan kebawah seperti kata "iklil" yang berarti mahkota, karena ia melingkari kepala. Seseorang dapat disebut kalâlah manakala ia tidak mempunyai keturunan dan leluhur (anak dan ayah). Kerabat, garis sisi disebut kalâlah karena berada di sekelilingnya dan bukan di atas atau di bawah. Kata kalâlah kemudian dipergunakan secara hakikat untuk seseorang yang tidak punya ayah dan anak. (Ibn Manzur, t.th: 142), sehingga ahli waris yang berhak menerima hak kewarisan pada saat itu hanyalah kelima anak Abdul Azis tersebut. Keberadaan saudara yang memperoleh hak kewarisan pada saat kalâlah ini dijelaskan oleh Allah SWT dalam surat al-Nisâ ayat 176. Di dalam surat al-Nisâ ayat 176 tersebut Allah SWT menjelaskan bagian furûdh yang dapat diterima oleh saudara. Oleh karena kelima anak Abdul Azis menggantikan posisi saudara pada saat pewaris dalam keadaan kalâlah, yang bagian saudara tersebut telah dijelaskan secara pasti oleh Allah SWT melalui surat al-Nisâ ayat 176, maka kedudukan mereka pada saat itu menjadi ahli waris yang memperoleh bagian furûdh.

Lebih lanjut, para ulama juga telah menjelaskan bagaimana ketentuan pembagian harta warisan terhadap anak saudara, serta berapa besar bagian hak yang dapat diterimanya terhadap harta warisan tersebut.

Secara garis besar, Hukum Kewarisan Islam menentukan dua macam ahli waris, yaitu ahli waris yang bagiannya telah ditentukan secara pasti dan tertutup di dalam al-Qur'an maupun Hadis Nabi SAW, serta ahli waris yang bagiannya masih terbuka karena besar bagiannya tidak ditentukan secara pasti. Ahli waris yang bagiannya telah ditentukan secara pasti itu di dalam Al-Qur'an bagian mereka tersebut dijelaskan dalam bentuk angka pecahan, yaitu $1 / 2,1 / 4,1 / 8$, $1 / 6,1 / 3$, dan $2 / 3$. Bagian mereka yang telah ditentukan ini dikenal dengan istilah furûdh. Para ahli waris yang mendapat bagian menurut angkaangka tersebut dinamai dengan ahli waris dzaul furûdh.

Di samping terdapat ahli waris yang bagiannya telah ditentukan 
tersebut, terdapat pula ahli waris yang bagiannya tidak ditentukan secara furûdh, baik dalam al-Qur'an maupun hadis Nabi SAW. Ahli waris ini mendapat seluruh harta dalam kondisi tidak adanya ahli waris dzaul furûdh, atau mendapat sisa harta setelah dibagikan terlebih dahulu kepada dzaul furûdh yang ada. Dengan demikian, mereka mendapat bagian yang tidak ditentukan dan bersifat terbuka, dalam artian bagian mereka bisa banyak, bisa sedikit, atau bahkan tidak ada sama sekali.

Sehubungan dengan kewarisan anak saudara sebagaimana yang menjadi objek pembahasan dalam penelitian ini, dalam menentukan besar bagian hak kewarisan yang dapat diterimanya (oleh anak saudara), terlebih dahulu harus melihat kepada besar bagian hak kewarisan yang diterima oleh saudara (oleh ayahnya). Karena pada prinsipnya anak saudara posisinya adalah menggantikan posisi saudara dalam menerima hak kewarisan (disebabkan saudara telah terlebih dahulu meninggal dunia). Sehingga besar hak kewarisan yang diterima oleh anak saudara adalah sebesar hak yang diterima saudara.

Dalam menentukan besar bagian yang diterima oleh anak Abdul Azis, terlebih dahulu dilihat kepada besar hak kewarisan yang di terima oleh Abdul Azis jika seandainya ia masih hidup. Hj. Syamsiar sebagai pewaris, pada saat ia meninggal dunia hanya meninggalkan ahli waris yang terdiri dari lima orang anak saudara kandungnya, yaitu anak dari Abdul Azis. Ia tidak meninggalkan kerabat/ahli waris lain kecuali berasal dari satu-satunya kerabat, yaitu Abdul Azis. Dengan demikian, jika seandainya Abdul Azis masih hidup pada saat $\mathrm{Hj}$. Syamsiar meninggal dunia, maka satu-satunya ahli waris $\mathrm{Hj}$. Syamsiar pada saat itu adalah Abdul Azis. Pada saat kondisi yang demikian itu, anak dari Abdul Azis tidak berhak memperoleh hak warisan karena terhijab oleh keberadaan Abdul Azis. Dengan demikian pada saat itu Abdul Azis berhak mewarisi seluruh harta peninggalan $\mathrm{Hj}$. Syamsiar.

Adapun yang menjadi dasar Abdul Azis berhak mewarisi seluruh harta Hj. Syamsiar adalah disebabkan karena pada saat itu Abdul Azis sebagai saudara laki-laki kandung $\mathrm{Hj}$. Syamsiar hanya sendirian. Tidak ada bersamanya ahli waris lain yang juga berhak terhadap harta peninggalan $\mathrm{Hj}$. Syamsiar. Ia adalah satu-satunya ahli waris yang ditinggalkan. Oleh karena itu ia mewarisi seluruh harta $\mathrm{Hj}$. Syamsiar. Ketentuan pembagian seperti ini oleh ulama Ahlu Sunnah disebut dengan konsep ashâbah, karena pada saat itu Abdul Azis berhak atas seluruh harta pewaris disebabkan ketiadaan dzaul furûdh (ahli waris lain) yang juga berhak atas harta warisan tersebut. Adapun posisi Abdul Azis pada saat itu ialah sebagai ashâbah bi al-nafsihi. Ia menjadi ashâbah bi-nafsihi disebabkan bersamanya tidak ada anak atau cucu laki-laki, serta ayah dari $\mathrm{Hj}$. Syamsiar (pewaris). 
Berdasarkan uraian di atas, dapat dipahami bahwa hak kewarisan yang diterima oleh Abdul Azis adalah seluruh harta peninggalan $\mathrm{Hj}$. Syamsiar. Dengan demikian, oleh karena Abdul Azis telah meninggal dunia terlebih dahulu dari pewaris, maka hak kewarisan terhadap seluruh harta peninggalan $\mathrm{Hj}$. Syamsiar tersebut beralih kepada anak-anaknya.

Dalam menentukan bagian mereka sebagai furûdh, besar bagian yang dapat diterima oleh masingmasing mereka dapat ditentukan berdasarkan furûdh yang dapat diterima oleh saudara laki-laki dan saudara perempuan. Dasar kewarisan saudara, baik laki-laki maupun perempuan, adalah firman Allah dalam surat al-Nisâ ayat 176. Dalam ayat ini Allah menjelaskan bagian furûdh yang dapat diterima oleh saudara laki-laki dan saudara perempuan.

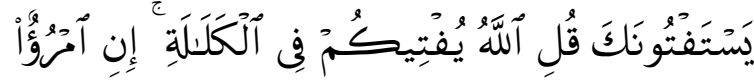

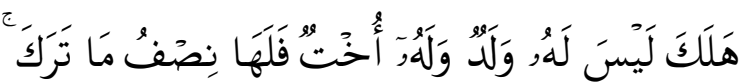

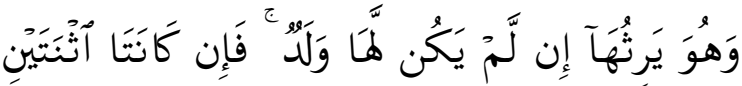

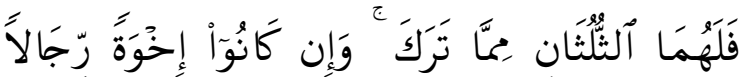

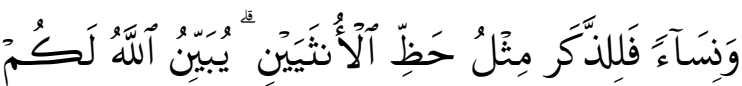

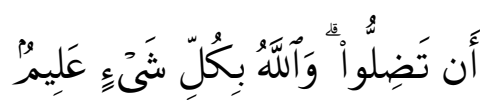

"Mereka meminta fatwa kepadamu (tentang kalâlah). Katakanlah: "Allah memberi fatwa kepadamu tentang kalâlah (yaitu): jika seorang meninggal dunia, dan ia tidak mempunyai anak dan mempunyai saudara perempuan, Maka bagi saudaranya yang perempuan itu seperdua dari harta yang ditinggalkannya, dan saudaranya yang laki-laki mempusakai (seluruh harta saudara perempuan), jika ia tidak mempunyai anak; tetapi jika saudara perempuan itu dua orang, Maka bagi keduanya dua pertiga dari harta yang ditinggalkan oleh yang meninggal. dan jika mereka (ahli waris itu terdiri dari) Saudara-saudara laki dan perempuan, Maka bahagian seorang saudara laki-laki sebanyak bahagian dua orang saudara perempuan. Allah menerangkan (hukum ini) kepadamu, supaya kamu tidak sesat. dan Allah Maha mengetahui segala sesuatu". (Q.S. An-Nisâ [4]: 176)

Berdasarkan ayat 176 surat al-Nisâ tersebut dapat dipahami bahwa terhadap saudara laki-laki dan saudara perempuan, terdapat ketentuan yang mengatur hak mereka, yaitu:

1. Jika saudara perempuan terdiri dari 1 (satu) orang saja, ia mendapat ${ }^{1 / 2}$

2. Jika saudara perempuan lebih dari 2 (dua) orang, mereka mendapat $2 / 3$

3. Saudara perempuan bersama dengan saudara laki-laki dengan bandingan pembagian seorang saudara laki-laki sama dengan dua orang saudara perempuan.

\section{PENUTUP}

\section{Kesimpulan}

Hukum Kewarisan Islam mengenal adanya hak kewarisan terhadap anak saudara. Kewarisan anak saudara ini secara jelas tidak terdapat di dalam alQur'an dan hadis Nabi SAW. Adanya hak kewarisan anak saudara ini pada dasarnya adalah melalui perluasan 
pengertian saudara yang haknya dijelaskan di dalam al-Qur'an, karena bila saudara sudah tidak ada, maka kedudukannya digantikan oleh anaknya. Anak saudara itu belum akan mendapatkan hak selama ayahnya yang menghubungkannya kepada pewaris masih hidup. Secara sederhana, hal ini dapat dipahami sebagai konsep "Perluasan Makna Saudara".

Putusan Pengadilan Agama Padang tentang Wasiat Wajibah yang menetapkan Rosmeily binti Abdul Azis memperoleh hak atas harta peninggalan ibu angkatnya Almarhumah Hj. Syamsiar melalui Wasiat Wajibah adalah kurang tepat. Hal ini disebabkan karena Rosmeily binti Abdul Azis memiliki hubungan kekerabatan yang sangat erat dengan Hj. Syamsiar. Abdul Azis yang merupakan ayah kandung Rosmeily, adalah saudara kandung dari $\mathrm{Hj}$. Syamsiar (pewaris, sekaligus ibu angkatnya). Oleh sebab itu Rosmeily lebih tepat memperoleh bagian terhadap harta peninggalan Hj. Syamsiar melalui haknya sebagai ahli waris, bukan sebagai penerima wasiat wajibah. Hal ini dikarenakan Rosmeily menggantikan posisi ayah kandungnya sebagai ahli waris karena telah terlebih dahulu meninggal dunia dari $\mathrm{Hj}$. Syamsiar. Rosmeily beserta 4 (empat) orang saudaranya berhak memperoleh bagian furûdh terhadap harta warisan $\mathrm{Hj}$. Syamsiar. Bagian furûdh yang mereka peroleh adalah berdasarkan pada surat alNisâ ayat 176. Pada dasarnya ulama sepakat bahwa ayat 176 surat al-Nisâ ini mengatur ketentuan furûdh bagi saudara kandung, atau saudara seayah. Oleh karena Rosmeily beserta 4 (empat) orang saudaranya menggantikan posisi ayah kandung mereka, maka ketentuan ayat 176 surat al-Nisâ ini dapat diberlakukan sebagai dasar penentuan furûdh bagi mereka.

\section{Saran}

1. Diharapkan bagi masyarakat yang ingin berperkara di pengadilan dalam artian menyelesaikan sengketa atau permasalahan hukum di pengadilan, terutama yang menyangkut dengan perkara perdata, hendaknya sebelum mengajukan surat permohonan/gugatan, terlebih dahulu harus benar-benar memahami duduk perkara serta akibat hukum yang ditimbulkan dari putusan hakim terhadap perkara tersebut nantinya. Masyarakat terlebih dahulu dapat berkonsultasi dengan orang atau lembaga yang memang bergerak dalam bidang jasa konsultasi hukum. Demikian juga bagi penasehat hukum, dalam menjalankan profesinya memberikan jasa bantuan hukum kepada masyarakat, hendaknya seorang penasehat hukum betul-betul memahami duduk perkara serta akibat hukum dari persoalan yang dhadapinya, sehingga masyarakat tidak merasa dirugian dengan putusan hakim.

2. Diharapkan agar para hakim di lingkungan Pengadilan Agama agar benar-benar memahami persoalan atau kasus yang sedang dihadapinya untuk menghindari terjadinya kekeliruan dalam penerapan hukum. Hakim harus memeriksa dengan seksama segala hal yang dapat menjadi bahan pertimbangannya dalam memutus perkara. Jika dipandang hal tersebut tidak memenuhi rasa keadilan, atau bahkan bertentangan dengan ketentuan al-Qur'an, Sunnah, maupun 
hasil ijma' ulama, hakim bisa saja memberikan putusan berupa penolakan terhadap permohonan atau gugatan para pihak.

\section{DAFTAR KEPUSTAKAN}

Alfiander, Dodon, 2015. Kewarisan Anak Angkat yang Berkedudukan Sebagai Ashâbul Furûdh (Analisis Terhadap Putusan Pengadilan Agama No. 287/Pdt.G/2006/PA.Pdg.). Tesis tidak diterbitkan. Padang: PPS IAIN IB Padang

Al-Nawâwî, Shahîh Muslim bi Syarh alNawâawî, Beirut: Dâr al-Fikr, 1972, jilid II

Al-Thusi, Abu Ja'far Muhammad Husain bin 'Ali, al-Mabsuth fi Figh al-Imâmiyah, Taheran: Maktabah alMurtadhawiyah, $\{$ t.th $\}$

Al-Turmudzi, Abi 'Isa Muhammad 'Isa ibn Sautah, Jamî' al-Shâhih Sunan al-Turmudzi, Dâr al-Kutub al'Ilmiyah, 2000, Juz. III
Al-Zuhailî, Wahbah, al-Figh al-Islami wa Adillatuhu, Damaskus: Dâr al-Fikr, 2002, Juz 10

Berkas Perkara No. 287/ Pdt. G/ 2006/ PA. Pdg.

Bisri, Cik Hasan, Kompilasi Hukum Islam dan Peradilan Agama dalam Sistem Hukum Nasional, Jakarta: Logos Wacana Ilmu, 1999

Ibn Manzur, Lisân al-'Arabi, Beirut: Dâr alFikr, [t.th], jilid XV

Instruksi Presiden (Inpres) Nomor 1 Tahun 1991 Tentang Kompilasi Hukum Islam (KHI)

J. Supranto, Metode Penelitian Hukum dan Statistik, Jakarta: Rineka Cipta, 2003

Kitab Undang-Undang Hukum Perdata (KUHPer)

Syarifuddin, Amir, Hukum Kewarisan Islam, Jakarta: Kencana, 2004

Undang-Undang Nomor 1 Tahun 1974 Tentang Perkawinan. 